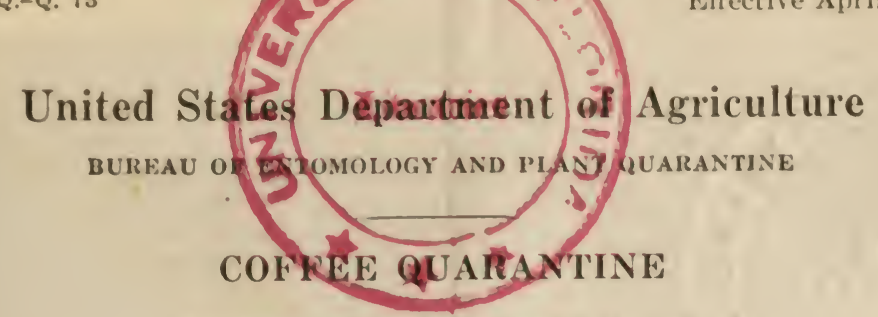

NOTICE OF QUARANTINE NO. 73

\title{
INTRODUCTORY NOTE
}

The coffee industry in Puerto Rico established early in the history of the Island has fortunately remained free from at least two of the world's most destructive coffee pests, the coffee berry borer and the coffee rust. The object of the present quarantine is to ensure the continued freedom of Puerto Rican coffee cultures from these and other coffee insects and diseases by prohibiting or restricting entry into the Island of those coffee materials which might be the means of introducing such pests. It is believed that the measures put into effect hy this quarantine will attain this end and at the same time provide for as much freelom of movement as would be consistent with safety.

$$
\begin{gathered}
\text { A A ERY S. IOYT, } \\
\text { Acting Chief, Bureau of Entomology and Plant Quarantine. }
\end{gathered}
$$

\section{SEC. 319.73-NOTICE OF QUARANTINE NO. 73 ON ACCOUNT OF COFFEE PESTS}

\author{
(Approved March 20, 1940 ; effective April 1, 1940)
}

Having found that an iujurious coffee insect (Stephunoderes [coffeae Hgdn.] hampri Ferr.), known as the coffe berry borer, and an injurious rust disease due to the fungus Hcmilcia vastatrix B. and Br., not heretofore widely prevalent or distributed within and throughout the United States, exist in various countries and localities throughout the world, I, Henry A. Wallace, Secretary of Agriculfure, pursuant to the provisions of the Plant Quarantine Act of August 20, 1912 (37 stat. 315; 7 C. S. C. 151-167), as amended, have determined that, in order to prevent the introduction of the said pests into the Island of Puerto Rifo, it is necessary to prohibit or restrict the importation into that Island from all foreign countries and localities of unroasted seeds or beans of coffee (Coffea spp.). coffee fruits or berries, and coffee plants and leaves.

Now, therefore, by virtue of the said Plant Quarantine Act, the public henring required therehy having been duly held, notice is herehy given, first, that on and after April 1, 1940, the importation into the Island of Puerto lieo from all foreign comntries and localities of (1) the seeds or beans of coffee which, previous to importation, have not been roasted to a degree which, in the judgment of an inspector of the Department of Agriculture, will have destroycul coffee borers in all stages, (2) coffee berries or fruits, and (3) coffer plants and leaves, is prohibited except by the Department of Agriculture for experimental and scientific murpreses, and except for samples of unroasted coffee sefels or beans, and for shipments of unroasted coffee seeds or beans in transit to destinations other than I'uerto Rico: and, second, that the importation of samples of unroasted eoffere specls or beans, and importations of umronsted coffee seeds or beans in transit to destinations other than Puerto Rico, shall be made only under the restrictions provided in the rules and regulations supplemental hereto: Provided, That iudividual shipments of nwaterials prohibited or restricted by this quarantine ma be pxempted from its provisions in whole or in part when it shall have been determined by the Chief of the Burean of Entomology and Plant Quaran- 
tine that entry of the shipment in question may be made without risk of pest introduction. ${ }^{2}$

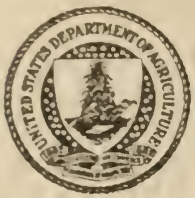

Done at the city of Washington this 20th day of March 1940.

Witnes $m y$ hand and the seapof the United States Department of Agriculture.

H. A. WALLACE:

Secretary of Agriculture.

\section{RULES AND REGULATIONS SUPPLEMENTAL TO NOTICE OF QUARANTINE NO. 73}

(Approved March 20, 1940 ; effective April 1, 1940)

\section{Regulation 1}

SEo. 319.73-1. Permit.-All importations shall be made under permit and only at the port of San Juan.

\section{Regulation 2}

SEc. 319.73-2. Inspection and Safeguard Provisions.-Coffee samples shull not exceed 1 pound in weight and may be imported by mail, freight, express, or baggage. They shall be subject on arrival to inspection and fumigation or such other treatment as the plant quarantine inspector may require. ${ }^{1}$

\section{Regulation 3}

SEc. 319.73-3. Restrictions on In-transit Shipments.-In-transit shipments to foreign countries shall be subject to the Plant Safeguard Regulations isisued October 4, 1932 (Secs. 352.2 to 352.8), or as hereafter revised. The same restrictions shall apply to shipments in transit to destinations elsewhere in the United States. ${ }^{1}$

These rules and regulations shall be effective on and after April 1, 1940.

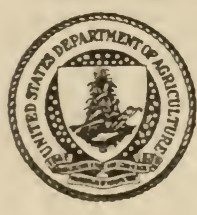
1940.

Done at the city of Washington this 20 th day of March

Witness my hand and the seal of the United States Department of Agriculture.

H. A. Wallace,

Secretary of Agriculture.

1 Secs. 319.73 to $319.73-3$ issued under authority contained in 37 Stat. $315 ; 7$ U. S. C. 151-167. 